\title{
A Poetic War Monument
}

If the Jael episode is indeed a later addition, then much of the account represents the work of later scribes who built on the work of their predecessors. These findings are of particular significance, since they reveal how an important biblical text grew exponentially as part of the war commemoration conducted by biblical scribes. We witnessed the same for the Rahab story in Part III. What's different about the case of Jael is that she represents an actual ethnic group (the Kenites). In the coming chapters, we examine various aspects of this woman's identity, but first we must consider what the Song of Deborah contributes to the account.

One of the earliest and most influential studies of biblical poetry is The Spirit of Hebrew Poetry: An Instruction for Lovers of the Same and the Oldest History of the Human Spirit, published in $\mathrm{I} 782-\mathrm{I} 783 .{ }^{\mathrm{I}}$ Its author the German philosopher, poet, theologian, and literary critic Johann Gottfried von Herder - was among the first European figures to think in terms of a national identity that transcends political borders, and Deborah's song was of special significance to him not only because he considered it to be older than most other biblical texts but also because he regarded it as proof that a people - like the tribes of ancient Israel and the divided German principalities of his own day - didn't need a common ruler to be united in spirit.

Thanks to Herder, most scholars today deem the Song of Deborah to be a very ancient, if not the most ancient, exemplar of Israelite poetry.

I Johann Gottfried von Herder, Vom Geist der ebräischen Poesie, ed. Karl Wilhelm Justi, 3rd ed. (Leipzig: J. A. Barth, I825). 
According to this view, the prose version that precedes the song was composed centuries later in order to provide a more straightforward narration of the battle. At the beginning of the twentieth century, Julius Wellhausen revealed the merits of this approach, and it has since reigned as the academic consensus. ${ }^{2}$ More recently, a few scholars have drawn attention to late features of the song and argued that the reverse is the case - that it is a late lyrical retelling of the earlier prose account. ${ }^{3}$

My own approach abolishes this simple alternative. ${ }^{4}$ I consider the song to have originally consisted of a generic hymn to the divine warrior, similar to many other biblical exemplars. Before being incorporated in the narrative and augmented with new lines, it had nothing to do with Deborah, Barak, or Jael. In what follows, I will illustrate this approach, considering not only how scribes transformed an older hymn into this impressive war monument but also why they did so.

\section{BETWEEN PROSE AND POETRY}

If the prose version of the Deborah-Barak account (Judg. 4) represents an attempt to "tell the story" contained in the song (Judg. 5), as widely assumed, one must explain why it doesn't mention Megiddo, Taanach, or "the kings of Canaan" (5:19), and why it describes a very different constellation of the participating tribes $\left(5: \mathrm{I}_{4}-\mathrm{I} 5\right)$. There are other discrepancies to be explained, such as the song's allusion to a dearth of weapons among the Israelites $(5: 8)$, which has no counterpart in the prose version.

On the other hand, if the song is a late poetic midrash on the prose version, as a handful of scholars now claim, one must account for numerous features that bear no connection whatsoever to the prose version, such as the pivotal place of Mount Tabor, Barak's ı०,000 troops, or Sisera's

${ }^{2}$ For a brilliant defense of this approach, see Baruch Halpern "The Resourceful Israelite Historian: The Song of Deborah and Israelite Historiography," Harvard Theological Review, 76 (I983), 379-40I.

3 This approach is more common in German scholarship; see, e.g., Christoph Levin, Fortschreibungen: Gesammelte Studien zum Alten Testament (Berlin: De Gruyter, 2003), I24-I4I.

${ }^{4}$ I discuss research on the song in "Deborah's War Memorial" and "War Commemoration and the Interpretation of Judges 5: 5 b-I 7." Among the more recent treatments, two stand out for the central place they occupy in the framework of important larger theses: Daniel Fleming, The Legacy of Israel in Judah's Bible (Cambridge: Cambridge University Press, 20I2); Mark Smith, Poetic Heroes: The Literary Commemorations of Warriors and Warrior Culture in the Early Biblical World (Grand Rapids: Eerdmans, 20I4). 
900 chariots. Moreover, we would expect the authors of the prose version to have seized upon the opportunity to portray as many tribes as possible participating in the battle, given that volunteerism is a major theme of Judges. Yet instead of depicting six tribes contributing to this war effort and four tribes shirking their duties, as the song does, the prose version names only two tribes.

References to Kishon are integral to the song, while in the prose version they appear to be supplementary. Deborah prophesies that Yhwh "will draw out Sisera to you [Barak]" (4:7). The following detail, "to the Kishon River," not only makes an unnecessarily detailed impression; it also conflicts with the emphasis on Mount Tabor as the place where Barak would descend and conquer the enemy (see 4:6, I2). In the description of that descent (4:I4), the river is not mentioned. Likewise, in the miraculous routing of Sisera's force (4:I5), Yhwh does not use water as a weapon; instead, he throws the enemy horses and the army into a panic a conventional "holy war" motif in the Bible. It's also difficult to explain why the prose version has nothing to say about the "kings of Canaan" or places such as Megiddo and Taanach (5:I9-2I).

The song is in many ways internally incongruous. For example, one strophe describes how the stars fight from heaven and the waters of Kishon miraculously sweep away Sisera and the Canaanite kings; the reader assumes that these enemies had been fully vanquished (5:19-23). Yet the following strophes present Sisera as still alive and well, resting in the tent of Jael. How he ended up in her abode is not explained. In fact, we do not even know the identity of this figure until four lines later. ${ }^{5}$

Here, as elsewhere, the song makes little sense by itself. If we assume the story was widely known through oral tradition, the gaps in the song's narrative would not have posed a problem. Such an appeal to oral tradition is speculative, however, and must be the ultima ratio in any analysis. A more plausible scenario is that scribes amplified the song with strophes that presuppose knowledge of the prose version. This scenario is even more likely if the Jael episode was added to the prose version, as argued in Chapter Io.

\section{REPURPOSING AN OLDER HYMN}

Within the song, it's relatively easy to distinguish two strands: one that is symbolic and mythical, and another that is concrete and realistic. The first

5 See vv. 24-27. The one line that does refer to him by name does not easily fit into the parallelism, so it's possible that 5:24-27 did not include his name. 
includes 5:2-5, 8-I I I3, I9, 2I-23, and 3 I. It resembles the style of not only Exodus 15 but also Psalm 68. Thus, it begins with an exordium (see Exod. I 5:I). Yhwh is described as coming out of Seir and Sinai as the earth trembles (see Ps. 68:8, I8). The people of Yhwh march down to fight a plurality of anonymous kings (see Ps. 68:13) in the Jezreel Valley, which, as noted, has long been one of the most popular battle sites in the southern Levant. These kings desire plunder but are swept away by primordial, chaotic waters (see Ps. 68:9-IO; Exod. I 5:8-10) in the form of the Kishon River.

The other strand comprises 5:6-7, I2, I 4-I 8, 20, and 24-30, and is much more concrete. Deborah rouses the troops to fight, and Barak leads them into battle. Sisera represents the anonymous enemy kings, and the description of his death at the hands of Jael, with his mother awaiting his triumphal return, is exceptionally graphic. This strand also dates events by reference to the historical chronology employed by the book of Judges ("the days of Shamgar/Jael").

The differences between the two strands in the song are perhaps most obvious when we compare verses $24-30$ to the peroration in verse $3 \mathrm{I}$. The former is realistic or even "naturalistic" in the technical sense, while the latter employs highly rarefied, mythical symbols.

Scholars who distinguish between these two strands often conclude that the concrete, realistic one ("the heroic epic") is older and that a later hand added more mythical, theological elements, which shift attention from human actors to the deity. ${ }^{6}$ However, this interpretation of the evidence fails to recognize that the "mythical" thread is intact, with a beginning and an end and that its form and themes have much in common with other biblical songs. Conversely, the historically concrete material of the heroic epic is hardly self-sustaining and lacks biblical parallels. It can easily be removed without inflicting structural damage to the song, and when one does so, the coherency and natural flow of an older hymn come to light:

Shamgar, Jael, and Deborah in verses 6-7. While it's difficult to understand exactly what is meant in 5:6-7, these lines draw undeniably on the figures, language, ideology, and historiographical principles from the surrounding narrative. Moreover, the theme of verses $4-5$ is closely connected to verses $8-9$. Both sections refer to the deity and the absence of

${ }^{6}$ What likely informs this view is the noticeable tendency in the book of Judges to introduce a pan-Israelite and Yahwistic overlay in older "profane" heroic material. While that tendency may be observed elsewhere, it should not prejudice the analysis of the song. 
arms in Israel's armies. The latter is a common topos in biblical prose and poetry and is consistently linked to the deity's direct intervention, as in verses $4-5$.

Deborah and Barak in verses $\mathrm{I}_{2}$ and $\mathrm{I}_{5}$. Verse $\mathrm{I}_{3}$ refers to those who march down to the battlefield. This theme begins already in verse I Ib: "Then down to the gates marched the people of Yhwh." In the transmitted form of the song, the line sticks out; it's also the only case where a colon stands isolated instead of in parallelismus membrorum. ${ }^{7}$ Yet after removing the appeal to Deborah and Barak in verse I2, which suddenly alternates from narrative-style to second-person address, we can see how the line is strikingly similar to, and anticipates, verse $\mathrm{I} 3 .{ }^{8}$ Both the action ("marched down") and the subject ("people of Yhwh") are consistent in these lines. That the mention of Deborah and Barak in verse $\mathrm{I} 5$ is secondary explains why the "catalogue of tribes" in verses I4-I 8 can be easily removed, revealing a tight connection between verses I 3 and I9: Israel marches down to engage the Canaanite kings in battle.

Sisera in verses I9-2I. In verse 2I, the river Kishon sweeps "them" away, yet the immediately preceding verse speaks of the stars fighting from heaven against one person, Sisera. To figure out who is meant by "them," we have to go back to verse I9, where the subject is "the kings of Canaan." They fight by "the waters of Megiddo" (i.e., the Kishon), yet they are unsuccessful in taking "ill-gotten gain." Why? Because "the river Kishon swept them away" (v. 2I; see vv. 3-5; cf. Exod. I 5:9-10). By removing verse 20 , these lines make much more sense. Alternatively, it is possible that only "with Sisera" was added to verse 20 . Whatever the case may be, most would agree that these lines read better without a reference to Sisera. If he were not a compositional afterthought, he could have easily been included in the formulation of verse 19 .

Jael and Sisera's mother in verses 24-30. The final line (v. 3I) expresses one of the fundamental themes of the song: the contrast between the perishing of Yhwh's enemies and the favor for those who "love" him

7 Not surprisingly, verse I $\mathrm{Ib}$ is subjected to the most radical of alterations by commentators, ancient and modern. Rashi, for example, reads it as describing the people returning to their dwellings from walled cities (or wishing to do so; see Ralbag).

${ }^{8}$ It is the same speaker, probably representing individual/collective Israel, as in verse 3 (see Exod. I 5:I). Alternatively, as in the Codex Vaticanus, one could read it as "him." Rashi resolves the repetition between verses I I and I 3 by interpreting the verb $y-r$ - $d$ in verse I 3 differently (viz., as "rule"). 
(cf. Ps. 68:2-3). Such love is the loyalty of vassals/allies who come to the help of their overlord/partner and offer him or her military assistance (one of the central components in international treaties). The theme of coming to Yhwh's help in wartime appears earlier in verses I I b and I3, but most explicitly in verse 23. Accordingly, the wish that "all Yhwh's enemies perish" in the final line continues the curse of Meroz, which is reminiscent of the imprecations in international treaties against a party for failing to contribute to a war effort.

The intervening strophes (vv. 24-30) dilate on the theme of the surrounding lines with a diptych that features the action of a loyal ally (vv. 24-27) and the reaction of the enemy's mother (vv. 28-30). The first passage portrays Sisera perishing at the hands of one of Yhwh's "friends" (see v. 3I) in an individual and concrete manner, and the anguish of Sisera's mother at the loss of her son segues into the final summation: "Indeed, may all your enemies perish ...." Similarly, "most blessed of women is Jael" (v. 24) stands opposite "cursed be Meroz" (v. 23).

The fact that these lines are well-suited to their context does not suffice as a reason to deny that they were likely introduced at a later point. Verse $3 \mathrm{I}$ is formulated in a style that differs sharply from the naturalism and realism in verses $24-30$, yet it resembles very closely the style of verses I9-23.

Supplements to the Song of Deborah

I On that day Deborah [and Barak son of Abinoam] sang: ${ }^{\text {? }}$

2 When locks go untrimmed in Israel, When a people/army offers itself willingly Bless Yhwh!

3 Hear, O kings!

Give ear, O potentates!

I am for [belong to] Yhwh, and I will sing,

I will make music for Yhwh,

For Yhwh God of Israel.

${ }_{4} \mathrm{O}$ Yhwh, when you came forth from Seir, Advanced from the country of Edom, The earth trembled, The heavens dripped, Yea, the clouds dripped water, 5 The mountains quaked,

9 The earliest stratum is in bold, with verse I perhaps as the introduction to the postulated hymn that was reworked into the song and thus being older than the other additions. (The translation provided here is based on that of the Jewish Publication Society.) 
Before Yhwh, the One of Sinai, Before Yhwh, God of Israel.

6 In the days of Shamgar son of Anath,

In the days of Jael,

Caravans ceased,

And wayfarers went

By roundabout paths.

7 Deliverance ceased,

In Israel it ceased,

Till I/you arose, Deborah,

$\mathrm{I} /$ you arose, a mother in Israel!

8 When they chose new gods,

The war was in the gates.

Was shield or spear to be seen

Among forty thousand in Israel?

9 My heart is with Israel's marshals,

With those who offered themselves freely among the people. Bless Yhwh!

Io You riders on tawny she-asses,

You who sit on saddle rugs,

You wayfarers, declare it!

I I To the sound of musicians among the watering places,

There let them chant the mighty deeds of Yhwh,

The mighty deeds of his peasantry in Israel.

Then did the people of Yhwh march down to the gates!

I 2 Awake, awake, O Deborah!

Awake, awake, strike up the chant!

Arise, O Barak;

Take your captives, $\mathrm{O}$ son of Abinoam!

I 3 Then down marched the remnant of/to the nobles,

Yhwh's people marched down for him/me with/against the mighty.

I4 From Ephraim came they whose roots are in Amalek;

After you, your kin Benjamin;

From Machir came down leaders,

From Zebulun such as hold the marshal's staff.

I 5 And Issachar's chiefs were with Deborah;

As Barak, so was Issachar,

Rushing after him into the valley.

Among the clans of Reuben

Were great searchings of heart. 
I6 Why did you stay among the sheepfolds

And listen as they pipe for the flocks?

Among the clans of Reuben

Were great searchings of heart!

I7 Gilead tarried beyond the Jordan;

And Dan - why did he linger by the ships?

Asher remained at the seacoast

And tarried at his landings.

[I 8 Zebulun is a people that spurned its soul to die,

Naphtali, on the open heights.]

I9 Then the kings came, they fought:

The kings of Canaan fought

At Taanach, by Megiddo's waters

They got no spoil of silver.

20 The stars fought from heaven,

From their courses they fought against Sisera.

2I The torrent Kishon swept them away,

The raging torrent, the torrent Kishon. -

March on, my soul, with courage!

22 Then the horses' hoofs pounded

As headlong galloped the steeds.

23 “Cursed be Meroz!" says the angel of Yhwh.

"Bitterly curse its inhabitants,

Because they came not to the aid of Yhwh,

To the aid of Yhwh with/against the warriors."

24 Most blessed of women be Jael,

Wife of Heber the Kenite,

Most blessed of women in tents.

25 He asked for water, she offered milk;

In a princely bowl she brought him curds.

26 Her [left] hand reached for the tent pin,

Her right for the workmen's hammer. -

She struck Sisera.

She crushed his head,

Smashed and pierced his temple.

27 At her feet he sank, lay outstretched,

At her feet he sank, lay still;

Where he sank, there he lay, destroyed. ${ }^{\text {Io }}$

Io Perhaps the interpolated Jael material consisted originally of this first section of the diptych (vv. 24-27) and was formulated with verse $3 \mathrm{Ia}$ in view ("So may all your enemies ....”). 
28 Through the window peered Sisera's mother,

Behind the lattice she whined:

"Why is his chariot so long in coming?

Why so late the clatter of his wheels?"

29 The wisest of her ladies give answer;

She, too, replies to herself:

30 "They must be dividing the spoil they have found:

A damsel or two for each man,

Spoil of dyed cloths for Sisera,

Spoil of embroidered cloths,

A couple of embroidered cloths

Round every neck as spoil."

3 I Indeed, may all your enemies perish, Yhwh! But may his friends be as the sun rising in its might!

Our analysis thus far has called into question two widely held views: I) that the song predates the prose version, and 2) that the prose version was written long afterward in order to fill in the gaps in the song. Why these views ever had purchase in biblical scholarship is due to the influence of nineteenth-century Romanticism, which regarded poetry as a more ancient mode of human expression than prose. Laying the groundwork for this view, Herder compared the song's imitative reenactment of the battle to victory rituals celebrated by other "uncivilized nations." II

If the Song of Deborah was originally not about Deborah and had nothing to do with the prose tale that precedes it, then why would the authors of Judges have selected it for their history? We noted that the song refers to a battle in the Jezreel Valley and so was well suited to the battle story in Judges 4. But why include a victory hymn in the first place? In Chapter Io, we observed how this hymn, together with the Song of the Sea in Exodus, demarcates an epoch of Yhwh's direct royal sovereignty in the narrative of Genesis-Kings. In the present chapter and those that follow, we pursue this line of inquiry and explore the ways in which scribes reworked this hymn to create a "national anthem" for Israel.

\section{A NATIONAL GOD AND ISRAEL'S UNITY}

War is one of the most powerful catalysts of political unification, and hence it is not surprising that the authors of Judges, like those of many other biblical books, treat the issue of national belonging in terms of

${ }^{\text {II } V o m ~ G e i s t ~ d e r ~ e b r a ̈ i s c h e n ~ P o e s i e, ~} 248$ 
wartime service and sacrifice. This issue is not central to the prose version of our story, though it does makes itself felt in the way a local narrative has been adopted and adapted to tell the story of the people of Israel as a whole. In the song, however, national belonging is argued directly through appeal to memories of military service and sacrifice performed on behalf of the nation's deity, not its ruling house.

The emphasis on Israel's unity under its national deity at a time of war is likely one of the primary reasons why scribes adopted the older hymn for their narrative. ${ }^{\mathrm{I} 2}$ The poet praises the people and the commanders of Israel who "offer themselves willingly" (vv. 2 and 9); each of these stanzas is punctuated with the refrain "Bless Yhwh!" ${ }^{3}$ Yhwh's victories and those of "his peasantry" are one and the same (v. I Ia). Similarly, the army of Israel is designated "the people of Yhwh" (vv. I I b, I3) or "those who love him" (v. 3I). The implication is that if one loves Yhwh, one will readily participate in the wars he fights on behalf of his people. This participation is described as "coming to the help of Yhwh," and those who fail to do so, such as the inhabitants of Meroz, are decisively cursed (v. 23).

Because it integrates disparate literary traditions, the song is characterized by a dizzying diversity of voices and actors. The heterogeneity is impressive, if not also occasionally confusing. What unites all these social classes, military ranks, regions, communities, and individual men and women is their collective identity, defined variously as "Israel," the children of "a mother in Israel," "the people/army of Yhwh," and "those who love him" (i.e., his vassals and allies).

Ancient military coalitions usually did not fight under the banner of a single deity; each member had its own leaders, god, and emblems. Hence, Sisera would not have expected the Kenites to embrace his god as their own. Yet a nation like Israel is more than an ad hoc military coalition; it is unified by deeper, enduring commitments. For the biblical authors, the deity was an ideal focal point in their project of consolidating

I2 As we saw in Part II, the older pre-Priestly and Deuteronomistic portions of Numbers 32 and related texts present the Transjordanian tribes swearing to fight for their kindred. However, in the later Priestly versions, they fight first and foremost for Yhwh, in accordance with the divine command communicated through Moses (=the Torah). Compare the way David's strategic raids are transformed to the wars of Yhwh (I Sam. 25:28).

I3 The expression "offer freely" appears frequently elsewhere in cultic contexts (see esp. Exod. 35). Throughout Ezra-Nehemiah, the expression constitutes a leitmotif that serves to highlight the various kinds of voluntary contributions as the defeated nation builds a communal life without a king of its own. 
rival communities. Although often divided by warring factions, these communities could appeal to Yhwh as the one who transcends political divisions and binds them all together as one people.

The expansion of the hymn with elements of the prose version in chapter 4 develops this theme of solidarity. Thanks to the inspiration of "a mother in Israel" (v. 7; contrast "the mother of Sisera" in v. 28), the nation's members volunteer for this war effort. Whole tribes and regions send down their officers and warriors, while others are rebuked for failing to participate. They come to the help of Deborah and the deity (vv. I3 and 23) instead of solely to relieve a beleaguered population. The prose version had already made Yhwh responsible for the triumph, and the addition of Deborah's prophecy and the Jael episode to the story likewise diminishes the role of the male hero (Barak) by making a woman responsible for the most valorous deed in the battle. In the song, Barak now joins Deborah in directing attention away from himself by lauding Yhwh and the myriad members of the nation "who offered themselves freely." With the addition of his name to the introduction in verse I (the verb is a singular feminine form), we are to understand that he came to fully embrace and internalize Deborah's perspective, relinquishing his quest for personal glory and paying tribute to Jael's culminating feat.

\section{RELIGIOUS UNITY AND AMERICAN NATIONAL IDENTITY}

According to a once popular interpretation, the song reflects the cultic celebration of a putative league of tribes in the pre-state period of Israel's history, and the register of tribes in 5:I4-I 8 constitutes an attendance list. ${ }^{\mathrm{I}}$ While such views have, with good reason, been abandoned in current scholarship, their proponents drew attention to an important feature of the song: the uniting of (rival) groups under the aegis of a single deity (see also 7:I 8, 20).

The depiction of a wide array of groups and individuals rallying around the deity in wartime is reminiscent of Karl Shapiro's poem "Sunday: New Guinea," which describes soldiers of all stripes and colors coming together to worship a single deity during the Second World War:

${ }^{14}$ See Volkmar Fritz, "The Complex of Traditions in Judges 4 and 5 and the Religion of Prestate Israel" in Aren Maeir and Pierre de Miroschedji (eds.), I Will Speak the Riddles of Ancient Times: Archeological and Historical Studies in Honor of Amihai Mazar on the Occasion of His Sixtieth Birthday, vol. 2 (Winona Lake: Eisenbrauns, 2006), 689-698. 
The bugle sounds the measured call to prayers,

The band starts bravely with a clarion hymn,

From every side, singly, in groups, in pairs,

Each to his kind of service comes to worship Him.

Citing this poem in her book GI Jews, Deborah Dash Moore discusses how the US armed forces during the early I 940 os made a concerted effort to foster solidarity and cohesion among Protestants, Catholics, and Jews, as well as all the denominations that constitute these three groups. ${ }^{{ }^{5}}$ In order to achieve this unity, the armed forces appealed to "the JudeoChristian tradition," a notion that has a prehistory but that was not widely embraced until the Second World War and thereafter. The navy hoped that an ecumenical doctrine, according to which all three religions worshiped the same deity, would provide common ground on which disparate religious and social factions could come together. Hence, lifeboats carried waterproof packages of pocket-sized Protestant, Catholic, and Jewish Bibles. According to the army's standard operating procedure, chaplains of one faith were required to minister to the soldiers of other faiths, and they were often expected to collaborate with chaplains of other faiths for common memorial services.

The impact on internal divisions within Judaism was profound. The Committee on Army and Navy Religious Activities (CANRA) formulated a tripartite Jewish denominationalism (Orthodox, Conservative, and Reform), and one of the most remarkable achievements was the agreement of the three denominations on a common Siddur (Jewish prayer book).

The Song of Deborah is in many ways an ancient precursor to the efforts of the US armed forces inasmuch as its formation was propelled and sustained by concerns to bring together rival communities as one people. Yet there are basic differences to be noted: CANRA sought to create a cultural and national unity by redefining Jews in terms of one of several legitimate religions ("faiths") that its members thought should define America's national identity. Moreover, instead of mobilizing an already existing nation for war, the biblical scribes were inventing what it means to be a nation, and they were doing so in the aftermath of defeat.

I5 Deborah Dash Moore, GI Jews: How World War II Changed a Generation (Cambridge, MA: Harvard University Press, 2004). 